\title{
Improving the Quality of Public Services Based on Information Technology through Development of Human Resources Management in Palembang
}

\author{
Hardiyansyah, Koesharijadi \& Suyanto \\ Universitas Bina Darma, Palembang, Indonesia.
}

Received: Sep. 14, 2017 Accepted: Oct. 16, 2017 Online published: Nov. 13, 2017

doi:10.5296/jpag.v7i4.11857ＵRL: https://doi.org/10.5296/jpag.v7i4.11857

\begin{abstract}
Facts show that the quality of public services based on information technology in Palembang Governance is still low because there are still many public complaints about the services provided. For example, completion of the provision of building permit, e-ID card, industrial business permit, trade license and other permits taking a long time and costing additional charges. This research was conducted for three years, for the first year, research method and approach used was quantitative method. In this research, there were 200 respondents from civil state apparatus in work unit of Local Governance of Palembang directly or indirectly involved in providing public services. Through statistical test using SPPS, it is found that simultaneously and partially the development of apparatus resources through the dimensions of learning, education, development and training greatly affect the quality of public services based on information technology in the Government of Palembang. Thus, it can be concluded that the more improved aspects of learning, education, development and training, then the quality of public services based on information technology will also increase.
\end{abstract}

Keywords: public services quality, apparatus development, information technology

\section{Introduction}

Human resource (apparatus) is the spearhead of successful implementation of regional autonomy policy. One indicator of the successful implementation of regional autonomy policy is the realization of well providing public services quality of implemented by public service organizations, such as electronic identity card making procedure, family cards, birth certificates, building permits, land certificates, trade licenses, etc. The public services quality nowadays has taken further steps to enhance their quality of service and increase the effectiveness of organizations characterized by creating an innovative ways to enable citizen-friendly environment, cheap, fast, and interactive relation public authorities and 
non-discriminatory. So far, the public service is still perceived as not qualified, it can be seen from various public complaints, whether delivered directly or complaints conveyed through various media, whether social media such as facebook, twitter, google ++ or mailing list, or through printed and electronical media such as newspapers or television and radio, including complaints to the Ombudsman institution, a state institution which has the authority to oversee the provision of public services, whether administered by a state-owned enterprise, a regional-owned enterprise, and a state-owned legal entity as well as a private or personal entity providing and organizing certain public services which part or all of their funds are from the budget of revenues and expenditures of state and/or regional budget and expenditure (RI, 2008).

In fact, after five years, Law No. 25 of 2009 issued on public service, complaints on poor public services until nowadays are still delivered Ombudsman of Indonesian Republic reports that the practice of undue delay still occurs in several government agencies. Undue delay is the top ranking for the type of maladministration reported by the citizens. The main problem related to the delays or late services by state agency, such as long delay permits issued by the local government, land certificate issued not well served by Land Agency office, delaying execution from court decisions, the absence of further investigation by the police, etc. In 2013, the percentage of undue delays occurred was fantastic. After undue delay issue, the other types of maladministration was $13.30 \%$ for the abuse of authority. The $18.07 \%$ was illegal procedure, then $13.67 \%$ for not providing services, and $9.24 \%$. maladministration was demanding charges money, goods and services or extortion. The practice of undue delay services adorned from the data of research and development from Indonesian Ombudsman gathered from the citizens' reports and complaints about the complexity of the bureaucratic process provided by government service agencies. the extended series of agency workflows resulted in the completion process exceeded the finishing time (Ombudsman, 2013).

Those claims and complaints indicate that the public service is considered not qualified. These conditions and situations resulted from two perspective overviews, internal and external perspective. From the internal perspective mainly caused by many officers who has low level formal education, there are 28.14 percent (BPS, 2014) officers are still graduated from senior high school or lower, various regulations and legislation are not well understood, there are still many apparatus seem technology shocked, and incapable or reluctant to use technological advances, there are still many sites (web) of local governments not utilized optimally and lack of service ethics, while the public demand for creating an innovative ways to enable citizen-friendly environment, cheap, fast, and interactive relation public authorities and non-discriminatory are still continued to be demanding as reformation demands and demands for the campaign promise from regional leaders.

Palembang with population of 1,611,309 people (BPS, 2014) also experienced the conditions described above. The supervision results from Indonesian Ombudsman in during two months indicated that a number of public services in Palembang had not been satisfactory. This was conveyed by the Deputy Chairman of the Indonesian Ombudsman Azlaini Agus in the Public Service Supervision seminar on Thursday, September 5, 2014, at Grand Zuri Hotel Palembang. Nine public service agencies were supervised, namely Office of Integrated 
Licensing Services of Palembang, One Roof System Administratin Services office (SAMSAT) of Palembang. Traffic Unit Office of Resort Police (Polresta) Palembang, First Class Immigration Office of Palembang. Population and Civil Registration Office of Palembang, National Land Agency Office of Palembang, Palembang Bari Public Hospital, Religious Affairs Office of District Ilir Barat I Palembang, and first class Prison of Palembang. The Indonesian Ombudsman conducted some basic tasks. Among other were, receiving and completing reports from claims or public complaints, investigating on self-initiative and supervising on public service provisions (Agus, 2016).

Based on the phenomena, facts and realities above, there is a gap between hope and reality. It is suspected that the occurrence of these situations and conditions, due to the development of human resources (apparatus) and utilization of information technology in public services have not been proceeded optimally. Good and qualified public services, not only as the demands of society in this reformation era, but also becomes a paradigm demands and the development of science and technology, especially information and communication technology.

\section{Literature Review}

\subsection{Human Resource (Apparatus)}

Human resource management is part of organizing process focuses on issues relating to the human resources aspects in an organization. Robbins (2006) argues that "Human resources management is the part of the organization that is concerned with the "people" or human resources aspect of management position, including recruiting, screening, training, rewarding, and appraising".

As an approach within an organization, human resource management emphasizes on human as the most valuable asset in the organization, supposing that human within an organization are able to work individually or collectively and contribute to the achievement of organizational goals. Regarding to the importance of human resources in the implementation and achievement of organizational goals, the need of the implementation of appropriate strategies in the implementation process of human resource management becomes an important. Implementation of human resource management in fact depends on the operational function of human resource management within an organization.

In addition to considering the operational functions of human resource management, it should be considered that human have characteristics that other resources do not possess, such as absolute prestige and dignity need to be recognized and appreciated, the mind and intelligence making them capable of constructive or destructive thinking, complex need of human makes it becomes more difficult to be identified, its distinctive background as reflected in its biographical characteristics, personality, abilities, value systems, personal motivation and perceptions of organization need to be considered in the of Human Resource Management (HRM).

Siagian (2000) says that some and other resources remain important and necessary, but they are only facilities and work infrastructures that allows an organization to perform its tasks. It 
is important to realize that for a human being these various resources and powers are merely "inanimate" and transform into "living tools" when mobilized and used by humans.

The concept of human resource development had been developed for long time. This development could be traced from apprenticeship training courses in the eighteenth century in small industries. Then it developed into a vocational education program followed by a technical or mechanical training program known as factory scholls in industrial revolution era. Followed by development of training program for semi-educated and uneducated workers. The condition of the workers at that time led to the emergence of the human relations movement which saw human beings as complex, not just the same as other factors of production. Hasibuan (2000) defines human resources as: "All human beings involved in an organization in seeking the realization of organization goals. The involvement itself means beneficiaries. Involvement can also mean input suppliers and implementers of activities ". According to Sedarmayanti (2009), human resources can be seen from two aspects, "Quantity aspect concerning the number of human resources, and quality aspects concerning the ability, both physical ability and non-physical ability related to ability to work, thinking, and other skills. Robbins (2006) defines the ability as: "the capacity of an individual to do various tasks in a job". In addition, that the overall abilities of an indivisu is essentially composed of two sets of factors there are: intellectual ability and physical ability.

Intellectual ability is the ability necessary to do or to perform mental activities. There are seven most commonly cited dimensions that make up the intellectual abilities, namely, numeracy skills, verbal comprehension, perceptual speed, inductive reasoning, deductive reasoning, space visualization, and memory while physical ability is the ability required to perform tasks demanding stamina, dexterity, limb strength, and similar skills (Robbins, 2006).

From various experts point of views, can be raised some elements or forms of human resource development activities process in this research uses the theory of human resources development proposed by Armstrong, which states that human resource is the most important property for an organization (Armstrong, 2006 ). Therefore, human resources must be trained seriously so that organizational goals can be achieved as expected. One of means that can be used by the management to carry out investment and training on human resources in the organization is to develop the human resources through the process of learning, education, development and training).

\subsection{Public Services}

One of the products of public organization is public service. Levine (1990) argues that the product of public service within a democratic state must at least meet three indicators. First, responsiveness or service provider responsiveness to the expectations, desires, aspirations and demands of service users. Second, the responsibility or a measurement indicates how far the process of public service delivery is carried out responsibly and in accordance with the principles and provisions of the administration and organization in well manner as assigned. Third, accountability is a measurement showing how much the process of service delivering in accordance with the interests of stakeholders and norms developed in society. 
According to Saefullah (2008) Public service is the service given to people who become citizens or who legally become residents of the country concerned. Thus, judging from the process, in public service there is an interaction between the giving service with the given service. The government as a bureaucratic institution functioning to provide services to people, while the population as the party giving the mandate to the government has the right to obtain services from the government. In practice, Saefullah argues that public services provided to the people can be distinguished in two major groups: 1) public services provided without regard to Personal individual, but given depending on general population needs, including the provision of transportation facilities and infrastructure, the provision of population centers and civil records, the construction of educational institutions, religious institutions, and etc; 2) individualized services, including citizen-friendly services, cheap, fast, especialy in obtaining ID cards and other licenses and permits, travel tickets, and so on.

In new public service model, the public service is based on democratic theory which teaches egalitarian and equality of rights among citizens. In this model, the public interest is formulated as a result of dialogue from various values in population, not formulated by the political elite stipulated in law. Bureaucracies in whom it provides public services should be accountable to whole people. The role of the government is to negotiate and explore various self-interest of citizens and various groups in community. In this model, the public bureaucracy must not only be accountable to the rule of law, but also to the values existing within the population, prevailing political norms, professional standards, and citizens' interests. This is an ideal series of public service concepts in democratic era.

Furthermore Dwiyanto (2006) argues that based on the paradigm of new public service as mentioned above, the ideal public services must be responsive to the various interests of public values that exist. The government's task is to negotiate and elaborate the various interests of the citizens in the community. It implies that the characters and values contained in the public service must contain the preference of values within the population. Because of the population is dynamic, so the character of public service must always change according to the population growth.

\section{Research Methods}

This research used quantitative approach through distributing questionnaires to respondents. The respondents were apparatus directly dealing with people in public service procedures in Palembang Governance, there were 200 people taken as sample using random sampling technique.

\section{Result and Discussion}

To support the description of the research results, the following is presenting the description of the research object (Profile of Palembang Governance), the characteristics of respondents and the results of descriptive data processing from human resource development (apparatus) and the quality of public services based on information technology in Palembang Governance. 


\subsection{Profile of Palembang Government}

Palembang is one of the metropolitan cities in Indonesia and geographically is located between $2^{\circ} 52$ 'to $3^{\circ} 5^{\prime}$ South Latitude and $104^{\circ} 37$ 'to $104^{\circ} 52^{\prime}$ East Longitude with an average height of 8 meters from sea level. The total area of Palembang City is $400.61 \mathrm{~km}^{2}$ which is administratively divided into 16 districts and 107 sub-districts. Palembang is the capital city of South Sumatera Province with boundaries as follows: The Northern regions are Pangkalan Benteng Village, Gasing Village and Kenten Village, Talang Kelapa district, Banyuasin Regency; Southern regions are Bakung Village, Inderalaya district, Ogan Ilir Regency and Gelumbang District, Muara Enim Regency; Western regions are Sukajadi Village, Talang Kelapa district, Banyuasin Regency; and the eastern regions are Balai Makmur village, Banyuasin I district, and Banyuasin Regency.

Based on the geological conditions, Palembang City has a diversed relief consisting of alluvial soil and sandy clay. In the southern part of the city, rocks are in the form of water-permeable clay sand, the northern part is waterproof sandstone clay, while the western is gravel clay, clay water-permeable sand.

\subsection{The Authority of Palembang Government}

The authorized compulsary duties of Palembang government are: (a) planning and controlling development; (b) planning, utilizing, and supervising of spatial city; (c) implementating of public order and public safety; (d) provisioning of public facilities and infrastructure; (e) public health servicing; (f) provisioning education service; (g) preventing of social problems; (h) employment services; (j) environmental controlling; (k) land services; (l) population services, and civil records; (m) public administration services; (n) investment and administration services; (o) other basic services; and (p) other mandatory matters mandated by legislation.

Furthermore, the government of Palembang City has optional affairs related to potentially and practically giving benefit in improving society welfare in accordance with the conditions, local specialty, and local features concerned. The government's optional affairs require vision based on carefulness, precision and responsibility on priority scaled development planning and concern to see the problems in line with people dynamics in Palembang.

According to the Regional Regulation of Palembang City Number 3 Year of 2001 on Formation, Position, Duty, Principal, Function and Organizational Structure of Regional Technical Institution, Civil Servant (PNS) working in Palembang government is divided into 3 major groups of work units namely Regional Secretariat, Department, and Agency and Office Centre of Palembang.

Based on Palembang Mayor's Regulation no. 32 Year of 2010 on Guidelines of Integrated Licensing Services of Palembang, there are 29 types of service permits issued by the Government of Palembang through the Licensing Services Office, among them are: Description of City Plan; Description of the Environmental Review; Hygienic Description and Sanitation; Swamp utilization permit; Operational Permit of Advertising Services Bureau; Advertising License Agreement; Building permit; Business Place Permit; Tourism Business 
License; Industrial License; Company Registration Permit; Trading Business License; Funeral and Custody License; Optical Organizing Permission; Pharmacy Administration License; Drug Store Operation Permit; Permit for Health Service Facilities for Basic Medical Field; Pharmaceutical Practice License; Licensed Pharmacy Assistant Practice and Associate Pharmacy Assistant; Midwife and Midwife Practice License; Nurse Work Permit; Dental Nurses Permit; Fishery Business License; Animal Cutting Permit; Regional Wealth Use Permit; Group C Material Mining Permit; City Road Utilization Permit; Liquid Waste Disposal Permit and Construction Service Business License.

\subsection{Characteristics of Respondents}

Human resources (apparatus) who are working in governance organizations are called civil state apparatus. To deploy a reliable and capable apparatus, almost all elements of government leadership always prioritize human resource development program (apparatus) than other programs. However, the implementation of human resource development (apparatus) is not always running as expected due to the unavailability of adequate budget allocated by the local government for the development of human resources (apparatus). Local governments prioritize budget allocations for physical development, the construction of roads, bridges, etc., because physical development will be resulting more visible directly by the citizens than the development of human resources (apparatus). Moreover, in the current reformation era, where their existence will depend on their respective constituents.

From total of 250 questionnaires distributed to the apparatus in the Palembang Governance, returned questionnaires and declared valid were 200 questionnaires where the discussion will refer to. To find out more clearly about the profile of respondents, the researcher presents the composition of respondents by gender, age, education level, and years of service, as follows: Female respondents were $56 \%$, male respondents were $44 \%$, respondents age dominated by 31- 40 years were $41.7 \%$, and for education level, the most dominant respondents were bachelors (S1) as much as $61.0 \%$ and the most dominants for work period were from 6 to 10 years, or $29.8 \%$.

\subsection{Validity Test}

In this research, constructive validity test was used to prove the homogeneity of the instrument. To find the results, the correlation values of each question item were calculated and then compared with the $r$ table value as an indicator of consistency between item scores and the overall scores. $r$ table score obtained from critical $r$ table, with 200 respondents then the df value was $n-2$ or $200-2=198$ so the $r$ table value was 0.1388 . The variable item is valid if the value of $r$ obtained $>r$ table, so the result from the validity test from the questionnaire for variable $\mathrm{X}$ showed that one of statement items was invalid so the statement was not included in the calculation and subsequent analysis.

\subsection{Reliability Test}

Reliability is the level of significant coefficient from measurement results. Significant reliability is a measurement which provides reliable results. Eventhough theoretically claims that the reliability coefficient is about 0.00 to 1.00 , in reality the coefficient of 1.00 is never 
reached in measurement because the research subject is human beings consisting a potential source of errors. This research used alpha cronbach method to show the reliability of the instrument. The alpha value can be interpreted as the correlation coefficient ranging between 0 and 1 . The higher the alpha value, the higher the reliability of the instrument, in other words the measurement error becomes lower. Reliability test results conclude wether or not the test instrument used is reliable.

\subsection{The Result of Estimated Multiple Regression Model}

The result of estimated regression model on the influence of Human Resources Development (learning, education, development and training) towards public services quality based on information technology. The result can be seen briefly in the following table:

Table 1. Analysis of multiple regression model

\begin{tabular}{|c|c|c|c|c|c|c|c|c|c|c|}
\hline \multicolumn{11}{|c|}{ Model Summary ${ }^{\mathrm{b}}$} \\
\hline \multirow[t]{2}{*}{ Model } & \multirow[t]{2}{*}{$\mathrm{R}$} & \multirow{2}{*}{$\begin{array}{c}\mathrm{R} \\
\text { Square }\end{array}$} & \multirow{2}{*}{$\begin{array}{c}\text { Adjusted } \\
\text { R } \\
\text { Square }\end{array}$} & \multirow{2}{*}{$\begin{array}{c}\text { Std. Error } \\
\text { of the } \\
\text { Estimate }\end{array}$} & \multicolumn{5}{|c|}{ Change Statistics } & \multirow[t]{2}{*}{ Durbin-Watson } \\
\hline & & & & & $\begin{array}{c}\text { R Square } \\
\text { Change }\end{array}$ & $\begin{array}{c}\mathrm{F} \\
\text { Change }\end{array}$ & df1 & $\mathrm{df} 2$ & $\begin{array}{c}\text { Sig. F } \\
\text { Change }\end{array}$ & \\
\hline 1 &, $796^{\mathrm{a}}$ & ,634 &, 627 & 4,83333 & ,634 & 84,461 & 4 & 195 &, 000 & 1,897 \\
\hline
\end{tabular}

a. Predictors: (Constant), TRAINING, DEVELOPMENT, LEARNING, EDUCATION

b. Dependent Variable: PUBLIC SERVICES QUALITY BASED_IT

Before further analysis, classic estimation test and hypothesis test were conducted. There were several classical assumption test used in this research, namely normality test, multicolinear test, heterokedasticity test, and autocorrelation test, the test were analyzed using simultaneous test (F test), partial test ( $t$-test) and Determination Coefficient test (R2).

\subsection{Classic Estimation Test}

The classic estimation test is an analysis conducted to detect the presence of any errors on a regression model follow a process. The multiple linear regression test requires data Best Linear Unbias Estimator (BLUE), to get BLUE data, it is necessary to conduct some analyses such as normality test, multicollinearity test, heterokedastisity test and autocorrelation test.

\subsection{The Linearity}

The Linearity testing between dependent and independent variable can be done by plotting residuals. When the residual plots follow a straight line for each additional value from independent and dependent variables, it is assumed that the model is linear. 


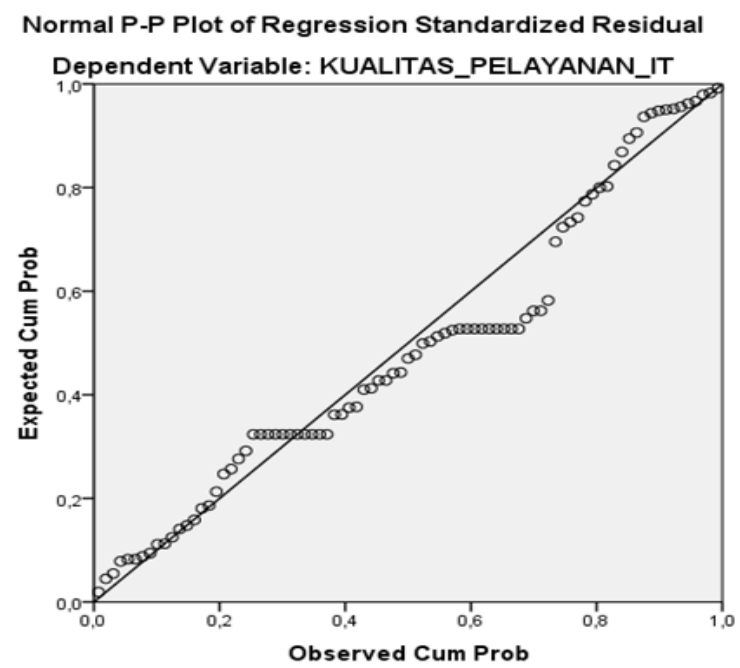

Figure 1 . The plot model of residual estimated linearity

Since the residual plot is close to a straight line then the estimation of linearity is met.

\subsection{Normality Test}

The purpose of normality test is to find out whether or not the regression model, the dependent variable, and the independent variable have both normal distribution, while the regression test aims to find out whether or not there is a significant influence between the dependent variable and the independent variables.

Based on the research, when the data is spread around the normal line and follows the diagonal direction, the regression model meets the estimation of normality and the regression model is normal.

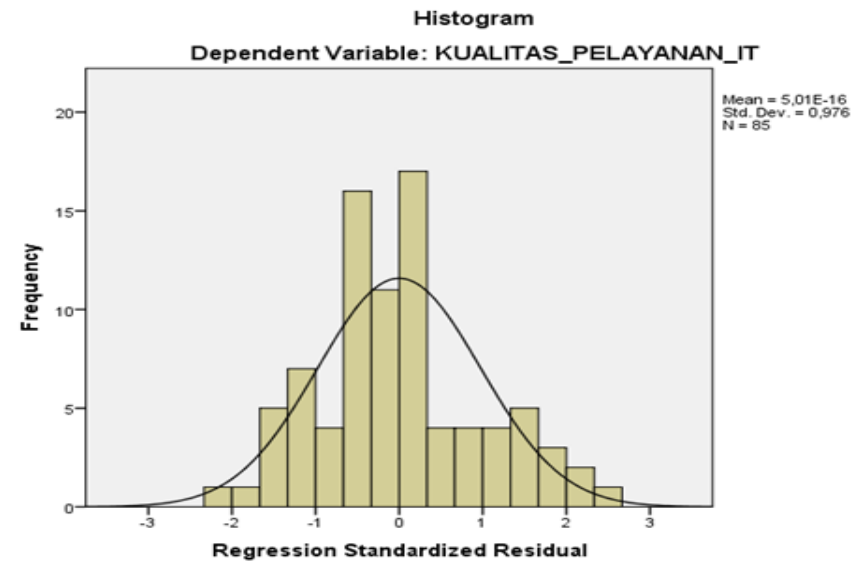

Figure 2. Normal Graph of Q-Q Plots and Normal Detrended of Q-Q Plots, observation values.

\subsection{Multicolinearity Test}

Multicolinearity means that the correlation between independent variables in regression model has perfect linear correlation or near perfect correlation. Multicolinearity test method 
is analyzed refers to tolerance Values and Inflation Factors (VIF) in the regression model

Table 2. Multicollinearity test results

Coefficientsa

\begin{tabular}{|c|c|c|c|c|c|c|c|c|c|c|c|}
\hline \multirow{2}{*}{\multicolumn{2}{|c|}{ Model }} & \multicolumn{2}{|c|}{$\begin{array}{c}\text { Unstandardized } \\
\text { Coefficients }\end{array}$} & \multirow{2}{*}{$\begin{array}{c}\begin{array}{c}\text { Standardized } \\
\text { Coefficients }\end{array} \\
\text { Beta }\end{array}$} & \multirow[t]{2}{*}{$\mathrm{t}$} & \multirow[t]{2}{*}{ Sig. } & \multicolumn{3}{|c|}{ Correlations } & \multicolumn{2}{|c|}{$\begin{array}{c}\text { Collinearity } \\
\text { Statistics }\end{array}$} \\
\hline & & B & $\begin{array}{l}\text { Std. } \\
\text { Error }\end{array}$ & & & & Zero-order & Partial & Part & Tolerance & VIF \\
\hline \multirow{5}{*}{1} & (Constant) & 15,220 & 5,450 & & 2,793 & ,006 & & & & & \\
\hline & LEARNING & 1,339 &, 182 & ,365 & 7,355 & ,000 & ,626 & ,466 & ,319 & ,763 & 1,310 \\
\hline & EDUCATION & 1,397 &, 214 & ,330 & 6,540 &, 000 & ,598 & ,424 & ,283 &, 738 & 1,355 \\
\hline & DEVELOPMENT & 1,295 & ,209 & ,302 & 6,208 & ,000 & ,565 & ,406 & ,269 & ,795 & 1,258 \\
\hline & TRAINING &, 372 &, 175 &, 102 & 2,122 & ,035 & ,370 &, 150 &, 092 & ,811 & 1,233 \\
\hline
\end{tabular}

a. Dependent Variable: PUBLIC SERVICES QUALITY BASED_IT

When the VIF value is smaller than 0.1 or VIF value is greater than 10 then multicolinearity is accepted, because the VIF value is less than 10 then this regression equation meets the criteria of not having multicollinearity.

\subsection{Heteroscedasticity Test}

The regression should not have heteroscedasticity, it is shown in the pattern of dots on the regression graph. If the dots do not form a clear pattern then it can be assumed there is no heteroscedasticity.

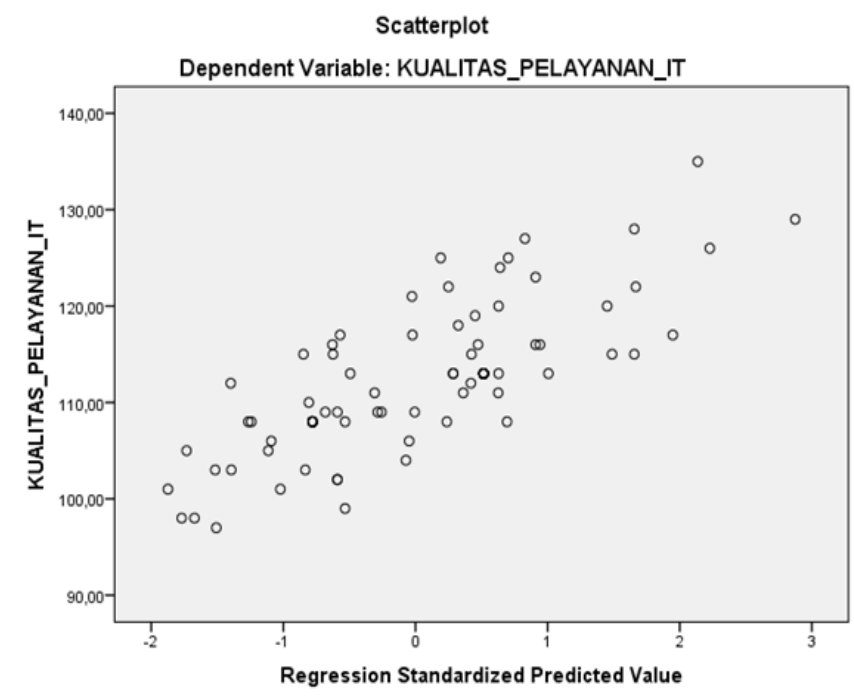

Figure 3. Scatter Diagram 


\subsection{Autocorrelation Test}

Autocorrelation test is found from Durbin Watson statistic value. Regression model indicates no autocorrelation if Durbin Watson (DW) value lies between 1.55 - 2.46

Table 3. Durbin Watson Value Terms

\begin{tabular}{ll}
\hline DW Value & Results \\
\hline Less than 1,10 & Autocorrelated. \\
1,10 and 1,54 & Inconclusive. \\
$\mathbf{1 , 5 5}$ and $\mathbf{2 , 4 6}$ & Not autocorrelated. \\
2,46 and 2,90 & Inconclusive. \\
More than 2,9 & Autocorrelated. \\
\hline
\end{tabular}

Based on table 3 and table 4, the value obtained lies between $1.55-2.46$. It indicates not autocorrelated.

Table 4. DW value regression model

\begin{tabular}{l|r|r|r|c|r|r|r|r|r|r}
\hline Model & $\mathrm{R}$ & $\mathrm{R}$ & $\begin{array}{c}\text { Adjusted } \\
\mathrm{R}\end{array}$ & \begin{tabular}{c} 
Std. \\
Error of \\
the \\
\cline { 5 - 7 }
\end{tabular} & $\begin{array}{c}\mathrm{R} \\
\text { Square }\end{array}$ & $\begin{array}{c}\text { Square } \\
\text { Change }\end{array}$ & $\mathrm{df1}$ & $\mathrm{df2}$ & $\begin{array}{c}\text { Sig. F } \\
\text { Change }\end{array}$ & \\
\hline 1 &, $796^{\mathrm{a}}$ &, 634 &, 627 & 4,83333 &, 634 & 84,461 & 4 & 195 &, 000 & 1,897 \\
\hline
\end{tabular}

a. Predictors: (Constant), TRAINING, DEVELOPMENT, LEARNING, EDUCATION

b. Dependent Variable: PUBLIC SERVICES QUALITY BASED_IT

Because Durbin Watson value is 1.897 it indicates not autocorrelated

\subsection{Hypothesis Test}

After ensuring that the data has been free from classical estimated errors then hypothesis testing is analyzed. Hypothesis analysis uses 2 (two) tests; $t$ test (Partial) to detect the presence of the partial influence of each independent variable towards dependent variables, and $F$ test (Simultaneous) to detect the presence of simultaneous influence of both independent variables towards dependent variable.

\subsection{Simultaneous Test Procedure (F Test)}

F-test $(\mathrm{Fh})$ or $(p<0,05)$ test is intended to test whether or not the variable of learning, education, development and training simultaneously influence the effectiveness / quality of public services based on information technology. To test the hypothesis, $F$ test is conducted by comparing $\mathrm{F}$ score with $\mathrm{F}$ table. When $F$ score $>F$ table indicates the estimated regression and the correlation coefficient is significant so that $\mathrm{H}_{0}$ is rejected and $\mathrm{Ha}$ is accepted. Or can also be seen from the level of significant alpha $(\alpha)=0.05$. If the significance value $>0,05$ then $\mathrm{H}_{0}$ is rejected and $\mathrm{Ha}$ is accepted. $\mathrm{H}_{0}$ : indicate that there is no significant simultaneous influence between the variables of learning, education, development and training on the effectiveness / quality of public services based on information technology. Ha: indicates that there is a significant simultaneous influence between variables learning, education, 
development and training on the effectiveness / quality of public services based on information technology

$\mathrm{F}_{(4,195)}=2,42$

F score $=84,461$

Table 5. Result F test (simultaneously)

Model Summary ${ }^{\mathrm{b}}$

\begin{tabular}{|c|c|c|c|c|c|c|c|c|c|c|}
\hline \multirow[t]{2}{*}{ Model } & \multirow[t]{2}{*}{$\mathrm{R}$} & \multirow{2}{*}{$\begin{array}{c}\mathrm{R} \\
\text { Square }\end{array}$} & \multirow{2}{*}{$\begin{array}{c}\text { Adjusted } \\
\text { R } \\
\text { Square }\end{array}$} & \multirow{2}{*}{$\begin{array}{l}\text { Std. } \\
\text { Error of } \\
\text { the } \\
\text { Estimate }\end{array}$} & \multicolumn{5}{|c|}{ Change Statistics } & \multirow[t]{2}{*}{ Durbin-Watson } \\
\hline & & & & & $\begin{array}{c}\mathrm{R} \\
\text { Square } \\
\text { Change }\end{array}$ & $\begin{array}{c}\mathrm{F} \\
\text { Change }\end{array}$ & df1 & df2 & $\begin{array}{c}\text { Sig. F } \\
\text { Change }\end{array}$ & \\
\hline &, $796^{\mathrm{a}}$ &, 634 & ,627 & 4,83333 &, 634 & 84,461 & 4 & 195 &, 000 & 1,897 \\
\hline
\end{tabular}

a. Predictors: (Constant), TRAINING, DEVELOPMENT, LEARNING, EDUCATION

b. Dependent Variable: PUBLIC SERVICES QUALITY BASED_IT

From the data analysis in table 5 above can be obtained the following results: by taking a significant level of $0.000(p<0.05)$ then $\mathrm{H} 0$ rejected and Ha accepted. In the result of variance analysis (ANOVA) can be seen that F score is 84,461 it indicates higher than $\mathrm{F}$ table F $0,05(4,195)=2,42$. Based on the analysis can be concluded for $F$ test obtained results H0 is rejected and $\mathrm{Ha}$ is accepted which means simultaneously among variables learning, education, development and training affect the effectiveness / quality of public services based on information technology.

\subsection{Partial Test (T-Test)}

The hypothesis analyses for partial test among the development of human resources / apparatus and the quality of public services based on information technology are as follows:

Ha1 : Assumed that there is a significant partial influence between the learning variable and the effectiveness / quality of public services based on information technology.

Ha2 : Assumed that there is a significant partial influence between the education variable and to the effectiveness / quality of public services based on information technology.

Ha3 : Assumed that there is a significant partial influence between development variable and the effectiveness / quality of public services based on information technology.

Ha4 : Assumed that there is a significant partial influence between the training variable and the effectiveness / quality of public services based on information technology.

Untuk melihat pengaruh secara parsial antara variable bebas terhadap variabel bergantung di lakukan uji t. To see the partial influence between independent variables and the dependent variable $t$ test was conducted.

Criteria of $F$ test 
If - $\mathrm{t}$ tabel value $\leq \mathrm{t}$ score $\leq \mathrm{t}$ tabel value so $\mathrm{H}_{0}$ is accepted

If $-\mathrm{t}$ tabel value $<\mathrm{t}$ score or $\mathrm{t}$ score $>\mathrm{t}$ table value, so $\mathrm{H}_{0}$ is rejected

or

If $\quad$ significancy $>0,005$, so $\mathrm{H}_{0}$ is accepted

If significancy $<0,005$, so $\mathrm{H}_{0}$ is rejected

To calculate $\mathrm{t}$ tabel value is significancy $=0,05 / 2=0,025$ with $\mathrm{df}=200-2=198$. From $t$ table obtained score $=1,972$ (see t-table 6$)$

Table 6. Results t Test (Partial)

\begin{tabular}{|c|c|c|c|c|}
\hline & Model & $\begin{array}{c}\mathrm{t} \\
\text { count }\end{array}$ & $\begin{array}{c}\mathrm{t} \\
\text { table }\end{array}$ & Test result \\
\hline & (Constant) & 2,793 & 1,972 & \\
\hline & Learning & 7,355 & 1,972 & \\
\hline 1 & Education & 6,540 & 1,972 & Ho rejected \\
\hline & Development & 6,208 & 1,972 & Ho rejected \\
\hline & Training & 2,122 & 1,972 & Ho rejected \\
\hline
\end{tabular}

Partially variables of learning, education, development and training have significantly influenced to the effectiveness / quality of public service based on information technology.

\subsection{Coefficient of Determination Test (R2)}

Based on the results of multiple linear regression analysis, it is found that the coefficient of determination denoted by R2 was 0.634 means that $63.4 \%$ of the effectiveness / quality of public services based on information technology is influenced by the variables of learning, education, development and training.

Model Regresi Linier: Linear Regression Model:

$\mathrm{Y}=15,220+1,339 \mathrm{X} 1+1,397 \mathrm{X} 2+1,295 \mathrm{X} 3+0,372 \mathrm{X} 4$

Table 7. Uji Koefisien Determinan

Coefficients $^{\mathrm{a}}$

\begin{tabular}{|c|c|c|c|c|c|c|c|c|c|c|c|}
\hline \multirow{2}{*}{\multicolumn{2}{|c|}{ Model }} & \multicolumn{2}{|c|}{$\begin{array}{c}\text { Unstandardized } \\
\text { Coefficients }\end{array}$} & \multirow{2}{*}{$\begin{array}{c}\begin{array}{c}\text { Standardized } \\
\text { Coefficients }\end{array} \\
\text { Beta }\end{array}$} & \multirow[t]{2}{*}{$\mathrm{t}$} & \multirow[t]{2}{*}{ Sig. } & \multicolumn{3}{|c|}{ Correlations } & \multicolumn{2}{|c|}{$\begin{array}{c}\text { Collinearity } \\
\text { Statistics }\end{array}$} \\
\hline & & B & $\begin{array}{l}\text { Std. } \\
\text { Error }\end{array}$ & & & & Zero-order & Partial & Part & Tolerance & VIF \\
\hline \multirow{5}{*}{1} & (Constant) & 15,220 & 5,450 & & 2,793 & ,006 & & & & & \\
\hline & LEARNING & 1,339 & , 182 & ,365 & 7,355 & ,000 & ,626 & ,466 & ,319 & ,763 & 1,310 \\
\hline & EDUCATION & 1,397 &, 214 &, 330 & 6,540 &, 000 & ,598 & ,424 & ,283 &, 738 & 1,355 \\
\hline & DEVELOPMENT & 1,295 & ,209 &, 302 & 6,208 &, 000 &, 565 & ,406 & ,269 & ,795 & 1,258 \\
\hline & TRAINING & ,372 & 175 & , 102 & 2,122 & ,035 & ,370 &, 150 & ,092 &, 811 & 1,233 \\
\hline
\end{tabular}


a. Dependent Variable: PUBLIC SERVICES QUALITY BASED_IT

Based on the results of statistical calculations as presented above, it can be concluded that simultaneously and partially "human resource development with dimensions of learning, education, development and training significantly influence the quality of public services based on information technology." These results in accordance with the research results conducted by Paranoan (2013) which suggests that the development of human resources through education and training has an impact on improving the ability to complete daily work, and in enhancing employee morale and trust while providing quality service. Quality of service is determined by the interaction of motivation in providing service and employee trust.

\section{Conclusion}

Based on the results of statistical calculations and discussion/analysis, it can be concluded that simultaneously and partially "the development of human resources with the dimensions of learning, education, development and training significantly influence the quality of public services based on information technology. This conclusion implies that the quality of public services based on information technology will increase when the human resources continue to learn, to develop, and providing opportunity to follow formal and informal education and they are facilitated to follow various training related to information and communication technology partially and simultaneously.

\section{Acknowledgement}

The research is financed by Research Grant Ministry of Research, Technology and Higher Education Republic of Indonesia Number 003/SPK/LPPM/Univ-BD/2017.

\section{References}

Agus, A. (2016). This is the result of ombudsman supervision in 9 agencies in Palembang (Inilah hasil supervisi ombudsman di 9 instansi di Palembang). Retrieved February 7, 2017, from http://infopublik.id/read/54521/inilah-hasil-supervisi-ombudsman-ridi-9-instansi-di-palembang.html.

Armstrong, M. (2006). Handbook of Human Resource Management Practice (10th Edition). London and Philadelphia: Koagen Page.

BPS. (2014). Palembang In Figures. Palembang: BPS (Central Bureau of Statistics) Palembang City.

Dwiyanto, A. (2006). Realizing Good Governance Serving Public. Yogyakarta: Gadjah Mada University.

Hasibuan, \& Malayu, S. P. (2000). Organization and Motivation. Jakarta: Bumi Aksara.

Levine, C., \& Frank, J. T. (1990). Public Administration. Challenges, Choice, Consequences. Illinois, USA: Scott, Little Foresman, Glenview. 
Ombudsman. (2013). The Annual Report of the Ombudsman of the Republic of Indonesia. Jakarta: Ombudsman RI.

Paranoan, A. B. (2013). Apparatus Resources Development Model to Improve Public Service Quality in Indonesia. Journal of Information Engineering and Applications. 3(3), 38-45

RI. (2008). Article 1 paragraph 1 of Law no. 37 of 2008 on the Ombudsman

Robbins, S. P. (2006). Organizational Behavior. Interpreter: Benjamin Molan. Tenth Edition. Jakarta: Publisher PT. Index.

Saefullah, H. A. D. (2008). Contemporary Thinking of Public Administration "Perspective of Human Resource Management in the Decentralization Era", Bandung: LP3AN FISIP UNPAD

Sedarmayanti. (2009). Human Resources and Work Productivity. Bandung: Mandar Maju Publisher.

Siagian, S. P. (1985). Organization, Leadership and Administrative Behavior. Jakarta: Gunung Agung.

\section{Copyright Disclaimer}

Copyright for this article is retained by the author(s), with first publication rights granted to the journal.

This is an open-access article distributed under the terms and conditions of the Creative Commons Attribution license (http://creativecommons.org/licenses/by/4.0/). 